\title{
Caldisericum exile gen. nov., sp. nov., an anaerobic, thermophilic, filamentous bacterium of a novel bacterial phylum, Caldiserica phyl. nov., originally called the candidate phylum OP5, and description of Caldisericaceae fam. nov., Caldisericales ord. nov. and Caldisericia classis nov.
}

Correspondence

Koji Mori mori@nbrc.nite.go.jp
Koji Mori, ${ }^{1}$ Kaoru Yamaguchi, ${ }^{1}$ Yayoi Sakiyama, ${ }^{1}$ Tetsuro Urabe ${ }^{2}$ and Ken-ichiro Suzuki ${ }^{1}$

${ }^{1}$ NITE Biological Resource Center (NBRC), National Institute of Technology and Evaluation (NITE), 2-5-8 Kazusakamatari, Kisarazu, Chiba 292-0818, Japan

${ }^{2}$ Department of Earth and Planetary Science, Graduate School of Science, The University of Tokyo, Bunkyo-ku, Tokyo 113-0033, Japan

\begin{abstract}
An anaerobic, thermophilic, thiosulfate-reducing bacterium, strain $\mathrm{AZM16c01}{ }^{\top}$, isolated from a hot spring in Japan [Mori, K., Sunamura, M., Yanagawa, K., Ishibashi, J., Miyoshi, Y., lino, T., Suzuki, K. \& Urabe, T. (2008). Appl Environ Microbiol 74, 6223-6229] was characterized in detail. The 16S rRNA gene sequence analysis had revealed that strain $\mathrm{AZM} 16 \mathrm{c01}{ }^{\top}$ was the first cultivated representative of the candidate phylum OP5. The cells were multicellular filaments with a single polar flagellum. The strain contained iso- $\mathrm{C}_{17: 0}$ as the major fatty acid and menaquinone- $8\left(\mathrm{H}_{6}\right)$, menaquinone- $8\left(\mathrm{H}_{8}\right)$ and menaquinone- $8\left(\mathrm{H}_{10}\right)$ as the respiratory quinones. The $\mathrm{G}+\mathrm{C}$ content of the genomic DNA of strain $\mathrm{AZM} 16 \mathrm{CO}^{\top}$ was 34.6 mol\%. Optimum growth was obtained at $65{ }^{\circ} \mathrm{C}, \mathrm{pH} 6.5$ and in the absence of $\mathrm{NaCl}$, with a doubling time of $10.6 \mathrm{~h}$. On the basis of the results of phylogenetic analysis based on the 16S rRNA gene sequence and the characterization of the strain in this study, we propose the name Caldisericum exile gen. nov., sp. nov. for strain AZM16c01 ${ }^{\top}$ (=NBRC $\left.104410^{\top}=\mathrm{DSM} 21853^{\top}\right)$. In addition, we propose the new phylum name Caldiserica phyl. nov. for the candidate phylum OP5 represented by C. exile gen. nov., sp. nov., and Caldisericaceae fam. nov., Caldisericales ord. nov. and Caldisericia classis nov.
\end{abstract}

A novel anaerobic, thermophilic, thiosulfate-reducing bacterium, strain $\mathrm{AZM} 16 \mathrm{c} 01^{\mathrm{T}}$, was isolated from a hot spring in Otari, Nagano Prefecture, Japan (Mori et al., 2008). Phylogenetic analysis based on the 16S rRNA gene sequence revealed that strain AZM16c01 ${ }^{\mathrm{T}}$ was not closely related to any of the recognized phyla and was reproducibly placed in a candidate phylum called OP5. The candidate phylum OP5 was represented originally by environmental clone sequences retrieved from the Obsidian Pool in Yellowstone National Park (Hugenholtz et al., 1998a) and indicated an independent phylum-level lineage in the domain Bacteria (Hugenholtz et al., 1998a, b; Mori et al., 2008; Rappé \& Giovannoni, 2003). Since then, environmental clone

The GenBank/EMBL/DDBJ accession number for the $16 \mathrm{~S}$ rRNA gene sequence of strain $\mathrm{AZM} 16 \mathrm{c} 01^{\top}$ is $\mathrm{AB} 428365$.

Graphs showing the effects of temperature, $\mathrm{pH}$ and $\mathrm{NaCl}$ concentration on the growth of strain $\mathrm{AZM} 16 \mathrm{cO} 1^{\top}$ are available as supplementary material with the online version of this paper. sequences belonging to this phylum have been detected in various environments (Dojka et al., 1998; Humayoun et al., 2003; Inagaki et al., 2006; Kaksonen et al., 2004; Ley et al., 2006; Skirnisdottir et al., 2000; Teske et al., 2002). Strain AZM $16 \mathrm{c} 01^{\mathrm{T}}$ was the first cultivable isolate accommodated in OP5. In the present study, we have characterized strain AZM $16 \mathrm{C} 1^{\mathrm{T}}$ in detail and propose the name Caldisericum exile gen. nov., sp. nov. for this strain. In addition, the higher taxa of the genus Caldisericum are proposed in this paper.

Cells of strain AZM16c01 ${ }^{\mathrm{T}}$ were multicellular filaments $(0.3 \mu \mathrm{m}$ in width and $1.6-8.3 \mu \mathrm{m}$ in length) with a single polar flagellum and formed complicated aggregates (Fig. 1 $\mathrm{a}-\mathrm{c})$. Observation of negative-staining with a transmission electron microscope (model H-7600; Hitachi) revealed that cells of strain AZM16 $01^{\mathrm{T}}$ possessed an envelope outside of the cell membrane (Fig. 1c). Although this envelope was sometimes observed in ultrathin sections, it was composed 

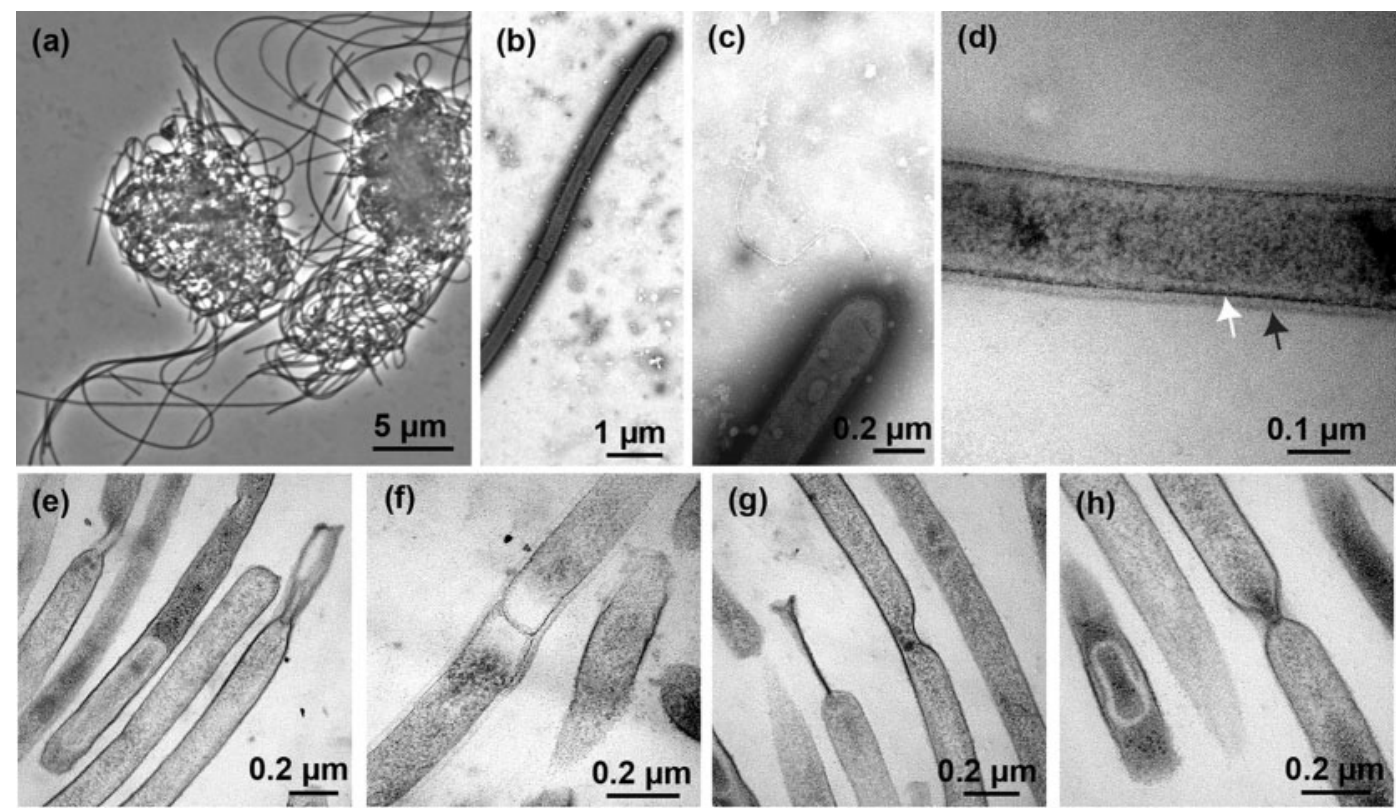

Fig. 1. (a) Phase-contrast and $(b-h)$ transmission electron micrographs of strain $A Z M 16 \mathrm{c} 01^{\top}$. Negatively stained cells are shown in (b) and (c). Ultrathin sections of cells are shown in $d-h$. (d) The cellular membrane and outer envelope are indicated by open and solid arrows, respectively. For the observation of ultrathin sections, cells were prepared by using rapid freezing and the freeze-substitution method with acetone containing $2 \%(\mathrm{w} / \mathrm{v})$ osmium tetroxide. After these procedures, cells were embedded in Spurr's resin (Spurr, 1969), stained with $0.5 \%(\mathrm{w} / \mathrm{v}) \mathrm{KMnO}_{4}$ and lead citrate (Reynolds, 1963), and observed using a transmission electron microscope (model H-7600; Hitachi) operating at $100 \mathrm{kV}$.

of an electron-lucent material and often could not be observed (Fig. 1d-h). The cell-wall structure of strain AZM16 $01^{\mathrm{T}}$ was shown to be Gram-negative, by using both conventional Gram-staining and Gram test with $3 \%$ (w/v) KOH (Powers, 1995). Stalk structures (Fig. 1e and g) and intracellular vacuole-like structures (Fig. 1e and h) were often observed. Motility and spore formation were not observed. Strain AZM16c01 ${ }^{\mathrm{T}}$ was negative for catalase and oxidase activities.

Cellular fatty acids, respiratory quinones and the genomic DNA G + C content were analysed using methods described previously by Mori \& Suzuki (2008). Strain AZM16 $011^{\mathrm{T}}$ possessed iso- $\mathrm{C}_{17: 0}(49 \%$ of the total fatty acids) as the predominant fatty acid; iso- $\mathrm{C}_{15: 0}(23 \%)$, iso$\mathrm{C}_{17: 0} 3-\mathrm{OH}(16 \%), \mathrm{C}_{16: 0}(8 \%)$ and anteiso- $\mathrm{C}_{17: 0}(4 \%)$ were also present. Strain $\mathrm{AZM} 16 \mathrm{c}_{0} 1^{\mathrm{T}}$ possessed the respiratory quinones menaquinone- $8\left(\mathrm{H}_{6}\right)$, menaquinone$8\left(\mathrm{H}_{8}\right)$ and menaquinone- $8\left(\mathrm{H}_{10}\right)(39,40$ and $21 \%$ of the total isoprenoid quinones, respectively). The genomic DNA G + C content of strain AZM16 $01^{\mathrm{T}}$ was $34.6 \mathrm{~mol} \%$.

For a detailed study of the cell envelope, we attempted to extract the cell wall to analyse its peptidoglycan content by using the method employed for Gram-positive bacteria (Schleifer \& Kandler, 1972; Yamaguchi, 1965); however, our attempt was unsuccessful. To investigate whether the component of the cell wall was peptidoglycan or protein Slayer, we observed negative-stained cells using an electron microscope after enzyme treatments with lysozyme [Nacalai Tesque; $2 \mathrm{mg} \mathrm{l}^{-1}$ in $10 \mathrm{mM}$ Tris buffer ( $\mathrm{pH} \mathrm{8)}$ containing $1 \mathrm{M}$ urea], proteinase $\mathrm{K}$ [Nacalai Tesque; $2 \mathrm{mg}$ $1^{-1}$ in $10 \mathrm{mM}$ Tris buffer $(\mathrm{pH} \mathrm{8})$ containing $1 \mathrm{mM}$ $\mathrm{Na}_{2}$ EDTA and $1 \mathrm{M}$ urea], proteinase mix (Pronase, Roche; $2 \mathrm{mg} \mathrm{l}^{-1}$ in $10 \mathrm{mM}$ Tris buffer containing $1 \mathrm{mM}$ $\mathrm{Na}_{2}$ EDTA and $1 \mathrm{M}$ urea) or trypsin (Nacalai Tesque; $2 \mathrm{mg}$ $1^{-1}$ in a solution comprising $1 \mathrm{mM} \mathrm{Na} \mathrm{NDTA}_{2}, 72 \mathrm{mM}$ $\mathrm{NaCl}, 2.6 \mathrm{mM} \mathrm{KCl}, 0.2 \mathrm{mM} \mathrm{NaH} \mathrm{PO}_{4} .2 \mathrm{H}_{2} \mathrm{O}$ and $1 \mathrm{M}$ urea, adjusted to $\mathrm{pH} 8$ with $8 \% \mathrm{NaHCO}_{3}$ ) at $37{ }^{\circ} \mathrm{C}$ for overnight. Compared with untreated cells in $10 \mathrm{mM}$ Tris buffer containing $1 \mathrm{M}$ urea, the cells treated with lysozyme, proteinase $\mathrm{K}$ and proteinase mix were shrunk in the envelope, but these digestions could not remove the envelope (data not shown). Because of these results, we could not come to a conclusion on the outer envelope structure. However, the detection of 3-hydroxy fatty acid in the cellular fatty acid analysis suggested that strain AZM $16 \mathrm{c} 01^{\mathrm{T}}$ possessed an outer membrane identical to that of Gram-negative bacteria.

As indicated in a previous report (Mori et al., 2008), strain $\mathrm{AZM} 16 \mathrm{c} 01^{\mathrm{T}}$ could grow on yeast extract but not on any other substrate in the presence of sulfur compounds (thiosulfate, sulfite and elemental sulfur) as electron acceptors. Optimum conditions for growth with $10 \mathrm{mM}$ thiosulfate and $10 \mathrm{~g}$ Bacto yeast extract $1^{-1}$ (Difco) were determined by assessing the time-course of optical density 
with a spectrophotometer (model U-2800; Hitachi) and the decrease in thiosulfate concentration by using HPLC (Mori \& Suzuki, 2008). The results are shown in Supplementary Fig. S1 (available in IJSEM Online). Strain AZM16c01 ${ }^{\mathrm{T}}$ could grow between 55 and $70{ }^{\circ} \mathrm{C}$, the optimum temperature being $65{ }^{\circ} \mathrm{C}$. The $\mathrm{pH}$ range for growth was 5.5-7.5 and the optimum $\mathrm{pH}$ was 6.5. Strain $\mathrm{AZM} 16 \mathrm{c} 01^{\mathrm{T}}$ was very sensitive to the $\mathrm{NaCl}$ concentration. Optimum growth was observed when no $\mathrm{NaCl}$ was added to the medium. Although growth was observed in 0.5 and $1 \%(\mathrm{w} / \mathrm{v}) \mathrm{NaCl}$, the cell concentration increased only scarcely and the amount of thiosulfate reduction was very slight. Strain AZM16 $01^{\mathrm{T}}$ had a doubling time of $10.6 \mathrm{~h}$ under the optimum growth conditions $\left(65^{\circ} \mathrm{C}, \mathrm{pH} 6.5\right.$ and in $0 \%$ $\mathrm{NaCl}$.

Phylogenetic analysis based on the 16S rRNA gene sequence (Mori et al., 2008) indicated that strain AZM $16 \mathrm{c} 01^{\mathrm{T}}$ belonged to the OP5 lineage (Fig. 2). This lineage was independent at the phylum level from other bacteria, and the branching point of the OP5 lineage was strongly supported with 93 and $97 \%$ bootstrap values by using the neighbour-joining and maximum-likelihood methods, respectively. The neighbour-joining tree of the OP5 phylum is shown in Fig. 3. This phylum consisted mainly of clone sequences obtained from anaerobic environments, and the sequence divergence for the phylum was $27.2 \%$.

The aim of this study was to characterize in detail strain AZM16 $01^{\mathrm{T}}$, isolated from the Otari hot spring. The phylogenetic analysis based on the 16S rRNA gene sequence revealed that strain $\mathrm{AZM} 16 \mathrm{c} 01^{\mathrm{T}}$ belonged in the OP5 lineage described by Hugenholtz et al. (1998a) and Rappé \& Giovannoni (2003). In addition, strain AZM16 $01^{\mathrm{T}}$ was not closely related to any of the known bacteria in recognized phyla, with less than $85 \%$ sequence similarity (Mori et al., 2008), and was sufficiently distinct to represent a new bacterial phylum (Hugenholtz et al., 1998a). The low DNA G + C content of strain AZM16c01 ${ }^{\mathrm{T}}$ and the presence of the highly saturated menaquinone- 8 in strain AZM16 $01^{\mathrm{T}}$ were not common in members of the domain Bacteria (Collins, 1994). Also, the fatty acid profile was typical of thermophiles and resembled particularly that of the phylum 'Deinococcus-Thermus' (Garrity \& Holt, 2001). Considering the morphological observations, although the occurrence of 3-hydroxy fatty acid strongly suggested the presence of an outer membrane containing lipopolysaccharide as observed for Gram-negative bacteria, it would be interesting to analyse the cell envelope of this

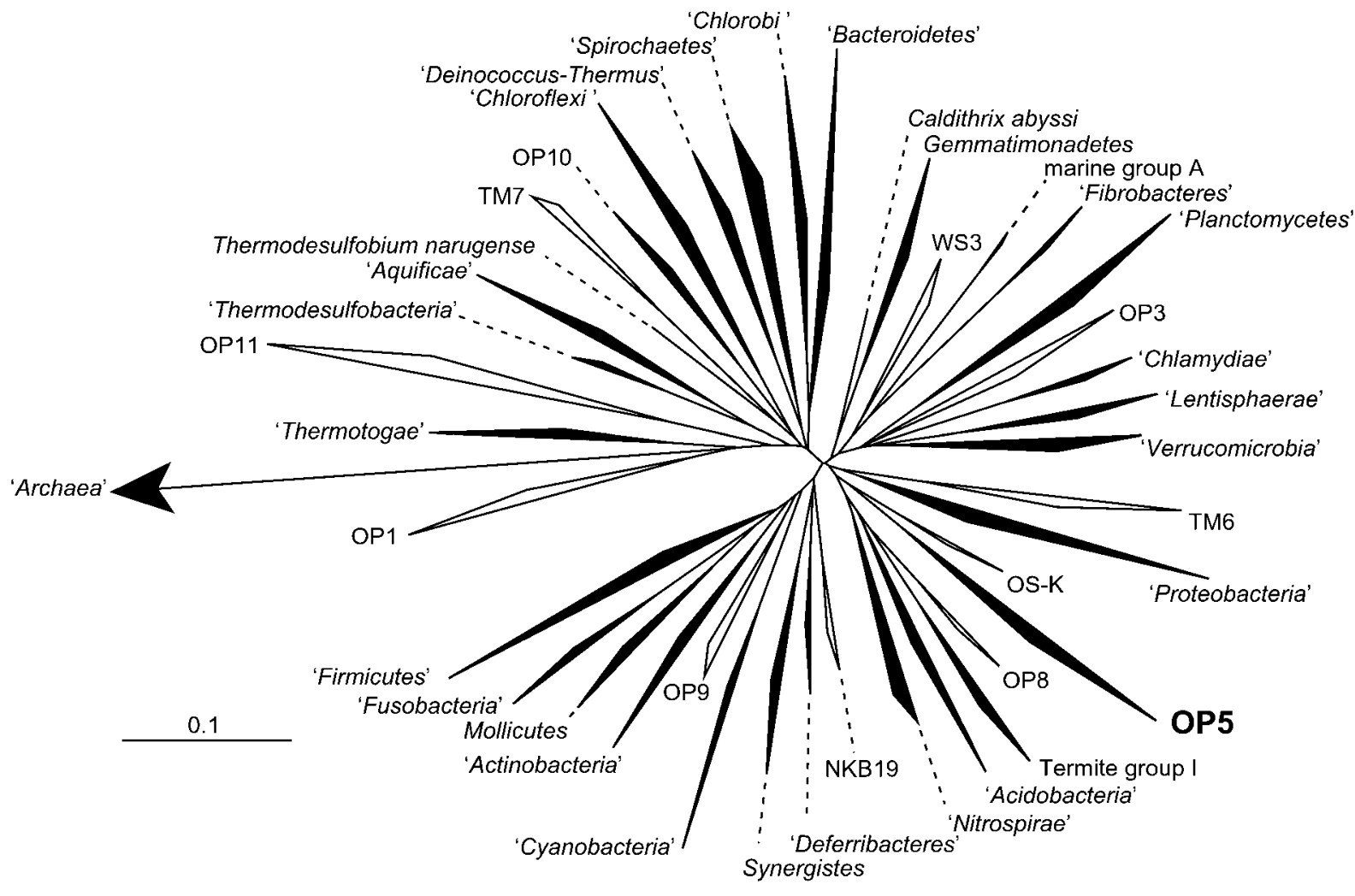

Fig. 2. Phylogenetic relationship based on $16 \mathrm{~S}$ rRNA gene sequences of strain $A Z M 16 \mathrm{c} 01^{\top}$ and major recognized bacterial phyla, inferred from the ARB program (Ludwig et al., 2004). Solid wedges indicate phyla with cultivated representatives and open wedges indicate phyla currently represented only by environmental clone sequences. Bar, 0.1 substitutions per compared nucleotide site. 


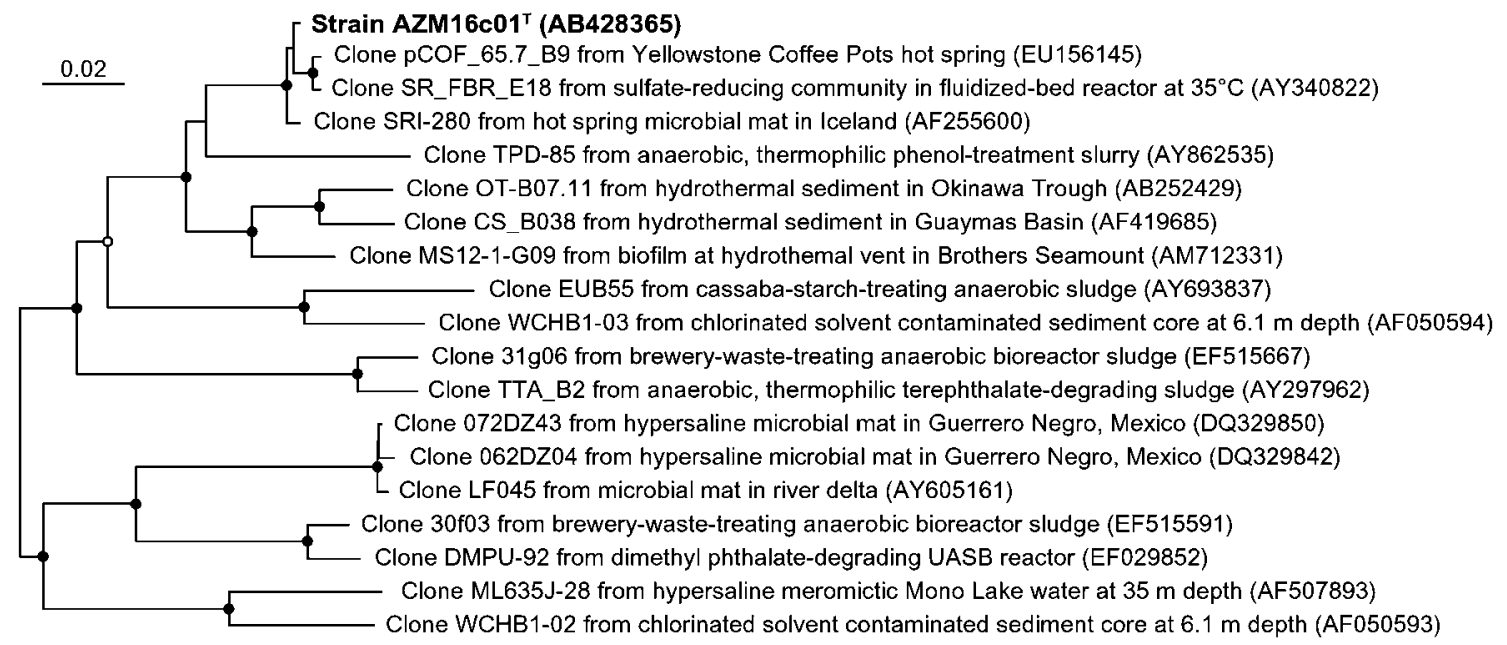

Fig. 3. Neighbour-joining tree based on $16 \mathrm{~S}$ rRNA gene sequences of strain $A Z M 16 \mathrm{c} 01^{\top}$ and environmental clones belonging to the OP5 phylum. The probability scores at branch points obtained using four analysis methods (neighbour-joining, maximumlikelihood, maximum-parsimony and Bayesian) are indicated by solid circles (above $95 \%$ by all methods) and open circles ( $>90 \%$ bootstrap probability supported by two methods). GenBank/EMBL/DDBJ accession numbers are shown in parentheses. Bar, 0.02 substitutions per compared nucleotide site.

organism in detail in a further study. In conclusion, the phylogenetic and physiological findings indicated that strain AZM $16 \mathrm{c} 01^{\mathrm{T}}$ represents a new genus and novel species within the candidate phylum OP5. Thus, we propose the name Caldisericum exile gen. nov., sp. nov. for this strain. In addition, corresponding to the candidate phylum OP5, we propose the phylum name Caldiserica phyl. nov., after $C$. exile, the first and sole representative of the phylum.

\section{Description of Caldisericum gen. nov.}

Caldisericum (Cal.di.se'ri.cum. L. adj. caldus hot; L. neut. n. sericum silk; N.L. neut. n. Caldisericum a silk existing in a hot environment).

Obligately anaerobic and chemoheterotrophic growth. Gram-negative. Filamentous morphology with an outer envelope. Thermophilic and non-halophilic. Spores are not formed. Cells are not motile. Growth occurs with anaerobic respiration using sulfur compounds. Respiratory isoprenoid quinones are menaquinone- $8\left(\mathrm{H}_{6}\right)$, menaquinone$8\left(\mathrm{H}_{8}\right)$ and menaquinone- $8\left(\mathrm{H}_{10}\right)$. The DNA G $+\mathrm{C}$ content of the type species is $34.6 \mathrm{~mol} \%$. Type species is Caldisericum exile.

\section{Description of Caldisericum exile sp. nov.}

Caldisericum exile (e.xi'le. L. neut. adj. exile slender).

Exhibits the following properties in addition to those given in the genus description. Cells are multicellular filaments, $0.3 \mu \mathrm{m}$ wide and $1.6-8.3 \mu \mathrm{m}$ long, with single polar flagella. Cells possess an outer envelope outside the cell membrane. Catalase- and oxidase-negative. Obligately chemoheterotrophic and anaerobic growth is observed with the reduction of sulfur compounds (thiosulfate, sulfite and elemental sulfur). Sulfate, fumarate, nitrate, nitrite and oxygen are not used as electron acceptors. Fermentation is not observed. Yeast extract is necessary for growth; the following substrates do not support growth: $\mathrm{H}_{2} / \mathrm{CO}_{2}, \mathrm{H}_{2}$ / $\mathrm{CO}_{2}+$ acetate, acetate, butyrate, formate, fumarate, glutamate, lactate, malate, propionate, pyruvate, succinate, Larginine, L-cysteine, arabinose, fructose, galactose, glucose, inositol, mannose, raffinose, sucrose, xylose, $\mathrm{CH}_{4}$, methanol, ethanol, 2-propanol, starch, Casamino acids (Difco), or polypeptone (Nihon Seiyaku). Temperature range for growth is $55-70{ }^{\circ} \mathrm{C}$, with optimum growth at $65^{\circ} \mathrm{C}$. $\mathrm{pH}$ range for growth is 5.5-7.5, with optimum growth at $\mathrm{pH}$ 6.5. Optimum growth occurs in the absence of $\mathrm{NaCl}$; growth is inhibited above $1 \%(\mathrm{w} / \mathrm{v}) \mathrm{NaCl}$. Major cellular fatty acid is iso- $\mathrm{C}_{17: 0}$; iso- $\mathrm{C}_{15: 0}$, iso- $\mathrm{C}_{17: 0} 3-\mathrm{OH}, \mathrm{C}_{16: 0}$ and anteiso- $\mathrm{C}_{17: 0}$ are also present. The DNA G $+\mathrm{C}$ content of the type strain is $34.6 \mathrm{~mol} \%$.

The type strain, AZM16c01 $1^{\mathrm{T}}\left(=\mathrm{NBRC} 104410^{\mathrm{T}}=\mathrm{DSM}\right.$ $\left.21853^{\mathrm{T}}\right)$, was isolated from a hot spring, Otari, Nagano Prefecture, Japan.

\section{Description of Caldisericaceae fam. nov.}

Caldisericaceae (Cal.di.se'ri.ca.ce'ae. N.L. neut. n. Caldisericum type genus of the family; suff. -aceae ending to denote a family; N.L. fem. pl. n. Caldisericaceae the family of the genus Caldisericum).

The description is the same as for the genus Caldisericum. Type genus is Caldisericum gen. nov. 


\section{Description of Caldisericales ord. nov.}

Caldisericales (Cal.di.se'ri.cal'es. N.L. neut. n. Caldisericum type genus of the order; suff. -ales ending to denote an order; N.L. fem. pl. n. Caldisericales the order of the genus Caldisericum).

The description is the same as for the genus Caldisericum.

Type genus is Caldisericum gen. nov.

\section{Description of Caldisericia classis nov.}

Caldisericia (Cal.di.se'ri.ci'a. N.L. neut. n. Caldisericum type genus of the type order of the class; suff. - $i a$, ending to denote a class; N.L. neut. pl. n. Caldisericia the class of the order Caldisericales).

The description is the same as for the genus Caldisericum.

Type order is Caldisericales ord. nov.

\section{Description of Caldiserica phyl. nov.}

Caldiserica (Cal.di.se' ri.ca. N.L. neut. n. Caldisericum type genus of the type order of the phylum; N.L. fem. pl. n. Caldiserica phylum of the genus Caldisericum).

The phylum Caldiserica is defined on a phylogenetic analysis based on 16S rRNA gene sequences of a sole isolated strain and uncultured representatives from various environments. Gram-negative bacteria with an outer envelope.

Type order is Caldisericales ord. nov.

\section{Acknowledgements}

We thank Kuniko Shimamura, Nobuyuki Goto and Yuumi Ishida for technical support. We gratefully acknowledge helpful discussions with Kenji Tanaka, Tomohiko Tamura, Masahito Suzuki, Kei Kamino and Fumiyoshi Okazaki on several aspects of the paper.

\section{References}

Collins, M. D. (1994). Isoprenoid quinones. In Chemical Methods in Prokaryotic Systematics, pp. 265-309. Edited by M. Goodfellow \& A. G. O’Donnell. John Wiley and Sons.

Dojka, M. A., Hugenholtz, P., Haack, S. K. \& Pace, N. R. (1998). Microbial diversity in a hydrocarbon- and chlorinated-solventcontaminated aquifer undergoing intrinsic bioremediation. Appl Environ Microbiol 64, 3869-3877.

Garrity, G. M. \& Holt, J. G. (2001). Class I. Deinococcoi class. nov. In Bergey's Manual of Systematic Bacteriology, 2nd edn, vol. 1, pp. 395420. Edited by D. R. Boone \& R. W. Castenholz. New York: Springer. Hugenholtz, P., Pitulle, C., Hershberger, K. L. \& Pace, N. R. (1998a). Novel division level bacterial diversity in a Yellowstone hot spring. J Bacteriol 180, 366-376.
Hugenholtz, P., Goebel, B. M. \& Pace, N. R. (1998b). Impact of culture-independent studies on the emerging phylogenetic view of bacterial diversity. J Bacteriol 180, 4765-4774.

Humayoun, S. B., Bano, N. \& Hollibaugh, J. T. (2003). Depth distribution of microbial diversity in Mono Lake, a meromictic soda lake in California. Appl Environ Microbiol 69, 1030-1042.

Inagaki, F., Kuypers, M. M., Tsunogai, U., Ishibashi, J., Nakamura, K., Treude, T., Ohkubo, S., Nakaseama, M., Gena, K. \& other authors (2006). Microbial community in a sediment-hosted $\mathrm{CO}_{2}$ lake of the southern Okinawa Trough hydrothermal system. Proc Natl Acad Sci U S A 103, 14164-14169.

Kaksonen, A. H., Plumb, J. J., Franzmann, P. D. \& Puhakka, J. A. (2004). Simple organic electron donors support diverse sulfatereducing communities in fluidized-bed reactors treating acidic metaland sulfate-containing wastewater. FEMS Microbiol Ecol 47, 279-289.

Ley, R. E., Harris, J. K., Wilcox, J., Spear, J. R., Miller, S. R., Bebout, B. M., Maresca, J. A., Bryant, D. A., Sogin, M. L. \& other authors (2006). Unexpected diversity and complexity of the Guerrero Negro hypersaline microbial mat. Appl Environ Microbiol 72, 3685-3695.

Ludwig, W., Strunk, O., Westram, R., Richter, L., Meier, H., Yadhukumar, Buchner, A., Lai, T., Steppi, S. \& other authors (2004). ARB: a software environment for sequence data. Nucleic Acids Res 32, 1363-1371.

Mori, K. \& Suzuki, K.-i. (2008). Thiofaba tepidiphila gen. nov., sp. nov., a novel obligately chemolithoautotrophic, sulfur-oxidizing bacterium of the Gammaproteobacteria isolated from a hot spring. Int J Syst Evol Microbiol 58, 1885-1891.

Mori, K., Sunamura, M., Yanagawa, K., Ishibashi, J.-i., Miyoshi, Y., lino, T., Suzuki, K.-i. \& Urabe, T. (2008). First cultivation and ecological investigation of a bacterium affiliated with the candidate phylum OP5 in hot springs. Appl Environ Microbiol 74, 6223-6229.

Powers, E. M. (1995). Efficacy of the Ryu nonstaining KOH technique for rapidly determining Gram reactions of food-borne and waterborne bacteria and yeasts. Appl Environ Microbiol 61, 3756-3758.

Rappé, M. S. \& Giovannoni, S. J. (2003). The uncultured microbial majority. Annu Rev Microbiol 57, 369-394.

Reynolds, E. S. (1963). The use of lead citrate at high $\mathrm{pH}$ as an electron-opaque stain in electron microscopy. J Cell Biol 17, 208-212.

Schleifer, K. H. \& Kandler, O. (1972). Peptidoglycan types of bacterial cell walls and their taxonomic implications. Bacteriol Rev 36, 407-477.

Skirnisdottir, S., Hreggvidsson, G. O., Hjorleifsdottir, S., Marteinsson, V. T., Petursdottir, S. K., Holst, O. \& Kristjansson, J. K. (2000). Influence of sulfide and temperature on species composition and community structure of hot spring microbial mats. Appl Environ Microbiol 66, 2835-2841.

Spurr, A. R. (1969). A low viscosity epoxy resin embedding medium for electron microscopy. J Ultrastruct Res 26, 31-43.

Teske, A., Hinrichs, K. U., Edgcomb, V., de Vera Gomez, A., Kysela, D., Sylva, S. P., Sogin, M. L. \& Jannasch, H. W. (2002). Microbial diversity of hydrothermal sediments in the Guaymas Basin: evidence for anaerobic methanotrophic communities. Appl Environ Microbiol 68, 1994-2007.

Yamaguchi, T. (1965). Comparison of the cell-wall composition of morphologically distinct Actinomycetes. J Bacteriol 89, 444-453. 